\title{
Differences in Gall Induction of Flower-like Galls on Haloxylon by Psyllids (Hemiptera: Aphalaridae), and the Emergence of Corresponding Parasitoids
}

\author{
Qian Zhao ${ }^{1,2} \oplus$, Ling-Ling Jiang ${ }^{1,2}$, Jie Guo ${ }^{1,2}$, Dong-Kang Zhang ${ }^{1,2}$ and Hong-Ying $\mathrm{Hu}{ }^{1,2, *(1)}$ \\ 1 College of Life Science and Technology, Xinjiang University, Urumqi 830046, China; ajazhq@163.com (Q.Z.); \\ Jlling_0727@163.com (L.-L.J.); guojie1824658155@163.com (J.G.); zhangdongkang0602@163.com (D.-K.Z.) \\ 2 Xinjiang Key Laboratory of Biological Resources and Genetic Engineering, Urumqi 830046, China \\ * Correspondence: huhongying@xju.edu.cn
}

Citation: Zhao, Q.; Jiang, L.-L.; Guo, J.; Zhang, D.-K.; Hu, H.-Y. Differences in Gall Induction of Flower-like Galls on Haloxylon by Psyllids (Hemiptera: Aphalaridae), and the Emergence of Corresponding Parasitoids. Insects 2021, 12, 861. https://doi.org/10.3390/insects12100861

Academic Editor: Andrew Polaszek

Received: 27 July 2021

Accepted: 17 September 2021

Published: 23 September 2021

Publisher's Note: MDPI stays neutral with regard to jurisdictional claims in published maps and institutional affiliations.

Copyright: (c) 2021 by the authors. Licensee MDPI, Basel, Switzerland. This article is an open access article distributed under the terms and conditions of the Creative Commons Attribution (CC BY) license (https:// creativecommons.org/licenses/by/ $4.0 /)$.
Simple Summary: Haloxylon spp. have been infested by various gall inducers, and natural enemies that impact pest populations must be understood to build integrated pest control strategies affecting pest dynamics. However, limited studies report on the gall inducers and parasitoids of flowerlike galls on Haloxylon, as well as the parasitic efficacy of the parasitoids. This study aimed to determine the main gall inducers that induced flower-like galls on Haloxylon ammodendron and H. persicum, and the parasitoid complex associated with them. In total, five species of gall inducers and three species of parasitoids were obtained from three types of flower-like galls on Haloxylon. Further, the parasitization indexes, emergence, and lifespan of parasitoids were also discussed. The present study may serve as a basis for understanding the importance of biological investigations of parasitoids in the gall inducers living in flower-like galls, which is important for pest control and the conservation of the ecological environment in the Haloxylon forest.

Abstract: Saxaul is a kind of dominant perennial psammophyte that widely distributes in arid and semiarid desert areas, and it has multiple functions in preventing desertification, especially in windbreak and sand fixation. Various gall inducers induce galls on the saxaul, including the flower-like gall. Parasitoids have great potentiality in controlling gall inducers. However, studies about gall inducers and parasitoids of flower-like galls on Haloxylon, as well as the parasitic efficacy of the parasitoids, are rarely reported. In this study, the flower-like galls were observed on Haloxylon ammodendron and H. persicum in Fukang, Xinjiang, China. Two types of flower-like galls were found on H. ammodendron, while only one type was found on $H$. persicum. In total, five species of gall inducers and three species of parasitoids were obtained from the galls mentioned above. All the galls were induced by Caillardia (Hemiptera: Aphalaridae), which were mostly bivoltine in Fukang. Besides, their parasitoids Psyllaephagus caillardiae and P. longiventris could be observed on all the types of galls. Additionally, correlative studies on the parasitization indexes demonstrated that all the dominant parasitoids of diverse flower-like galls were $P$. caillardiae, which were slightly more in number than the P. ogazae discovered in the flower bud-like galls. In addition, the relevance between the emergence or lifespan of parasitoids and temperature was also investigated. The results showed that the number of parasitoids emerging decreased rapidly after a period of enhancement with the increase of temperature, including an optimum temperature, while the lifespan of wasps gradually shortened with the temperature rising. Our results highlight the importance of the biological investigation of parasitoids in the gall inducers lived in closed galls, which may provide critical evidence for us to understand its potential application in biological control.

Keywords: Caillardia; Psyllaephagus; parasitization indexes; lifespan; biological control 


\section{Introduction}

Saxaul (Haloxylon spp. Bunge) is one of the most widely distributed sub-shrublets or shrubs in arid and semi-arid desert areas worldwide, with properties of drought resistance, cold tolerance, and strong adaptability to suit windbreak plantations and sand fixations [1,2]. Globally, 11 Haloxylon species have been recorded, of which two are distributed in Xinjiang (Xinjiang Uyghur Autonomous Region of China): the cosmopolitan Haloxylon ammodendron (C. A. Mey.) Bunge and H. persicum Bunge, a native species, is only distributed in the Junggar Basin in northern Xinjiang [3]. Besides, saxaul plays important roles in adjusting the vegetation climate and increasing biodiversity [2]. Thus, it is of profound significance to protect and rejuvenate the Haloxylon plant to control desertification and maintain the ecological balance in the region.

In addition to human activities, pests contribute significantly to the degradation of desert ecosystems. A variety of galls have been observed on the assimilated shoots, stems, and branches of seven species of Haloxylon spp. globally [4-8]. Five types of associated flower-like galls based on morphology have been identified on Haloxylon spp. (Figure 1) $[4,9,10]$. Leafy-bracted galls (G1) and flower like galls (G2) appeared with high frequency on H. ammodendron, while the leafy-bracted galls (G1) and flower like galls (G2 and G3) appeared with high frequency on H. persicum [8-10].

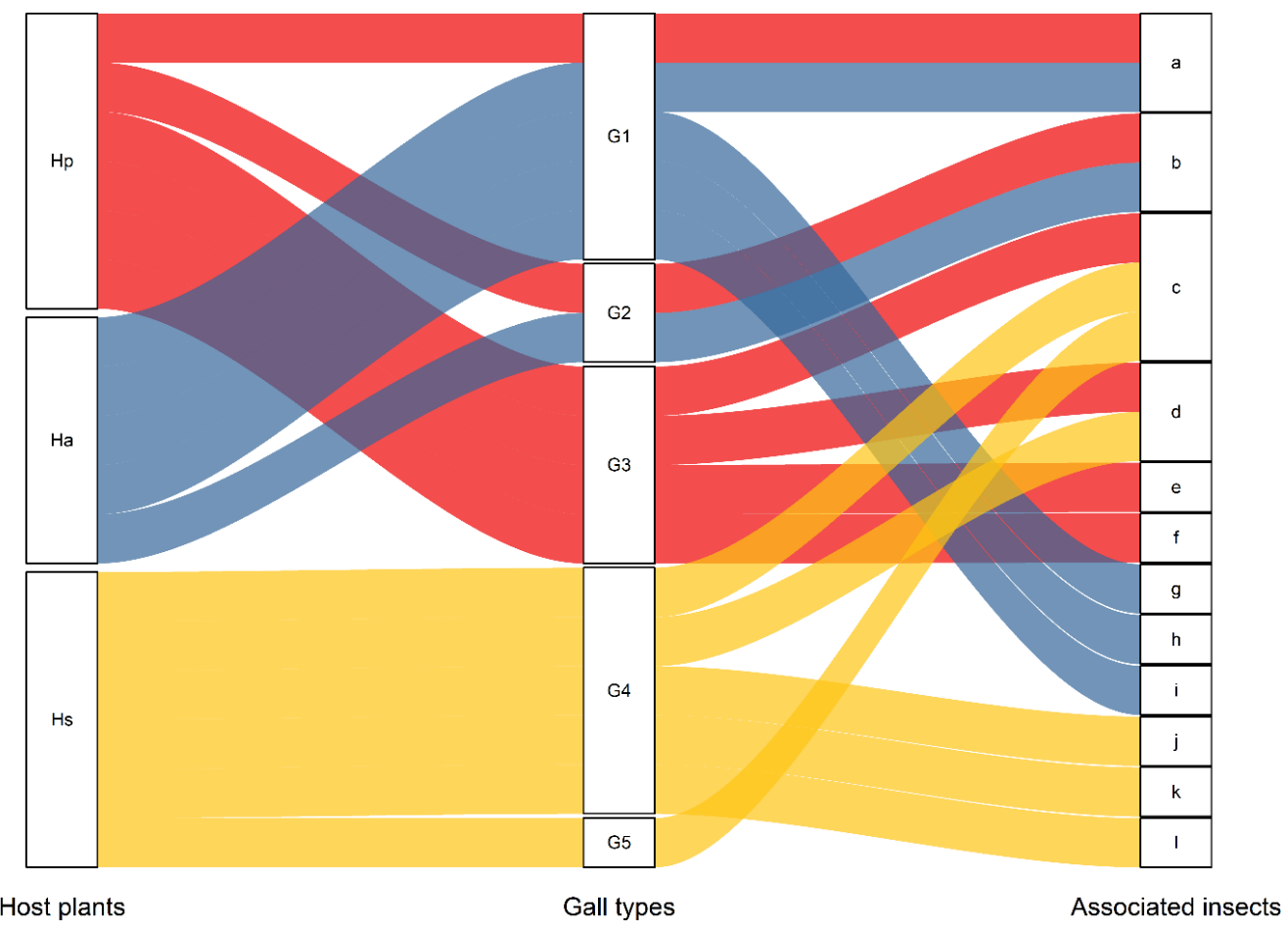

Figure 1. The relationships between the types of flower-like galls and their associated insects on three species of Haloxylon Worldwide. Hp: H. persicun, Ha: H. ammodendron,Hs: H. salicornicum; G1: leafy-bracted galls, G2-G4: flower-like galls, G5: spike-like galls; a-l indicate 12 species of associated insects. a: C. notata, b: Aceria haloxylonis, c: Pteromalidae, d: Thrips, e: Psyllidae, f: Pseudococcidae, g: C. robusta, h: C. azurea, i: C. nana, j: Pyralidae, k: Acari (Mites), l: Salticidae.

More than 17 species of gall inducers have been recorded that damage Haloxylon forest in the world [4-10]. These flower-like galls on H. persicum and H. ammodendron were associated with various pests that mainly belong to Psyllidae, Pyralidae, Pseudococcidae, and Thripidae. Moreover, psyllids are globally known as the major gall inducers on various organs of cultivated plants and forest trees, which are highly dependent on their host [11-17]. They have been recorded from the galls on Haloxylon frequently. At least four gall-forming species belonging to the genus Caillardia Bergevin (C. robusta, C. azurea, 
C. nana, and C. notata) were recorded and identified as the most harmful pests injuring Haloxylon aphyllum and H. persicum [18-23]. These species were first found in Kazakhstan and fed on the young twigs and leaves of Haloxylon $[19,20]$. These species showed a very distinct sexual dimorphism; they wintered in the egg phase and had two generations a year, but the gall type they induced was not reported. In China, these species were recorded from the leafy-bracted galls on H. ammodendron [9]. Consequently, these studies only illustrated that Caillardia spp. could make galls on Haloxylon, but little information is available about the species of the dominant gall inducer of each type of galls.

The control of gall inducers is important for the protection of the saxaul forest. However, the use of chemical insecticides, the dominant control method of gall inducers, has achieved limited success. It is also not a sustainable measure as it causes toxicities to beneficial nontarget organisms $[24,25]$. Thus, the adoption of an integrated pest management (IPM) strategy is better alternative for sustainable pest control [26-28]. Biocontrol is a promising component of IPM which involves the use of parasitic natural enemies to control pests, and several studies have reported on the biocontrol potentials of parasitoids [29]. For instance, the host-specific parasitoid Torymus sinensisis (Hymenoptera: Torymidae) was reported as an effective biological control agent of the chestnut gall wasp Dryocosmus kuriphilus Yasumatsu (Hymenoptera: Cynipidae) [30-33]. The species composition of insects, degree of pest damage, and abundance of natural enemies have been noted as primary factors affecting IPM strategy $[26,27,29,34]$. The species Psyllaephagus caillardiae Sugonjaev and P. ogazae Sugonjaev were firstly reported as parasitoids of the scanty gall psyllids, Caillardia robusta, C. azurea, and C. notata which formed galls on H. persicum and H. ammodendron [35] Likewise, Psyllaephagus sp. (Encyrtidae) was reported as the parasitoid of C. robusta, C. azurea, C. nana, and $C$. notata which caused galls on H. ammodendron and H. persicum in the Gurbantunggut Desert in Xinjiang, China [9]. A new species of Aprostocetus (Aprostocetus) essugonjaevi (Hymenoptera, Eulophidae: Tetrastichinae) was recorded in galls induced by the psyllids Caillardia spp. on H. persicum and H. ammodendron in Uzbekistan [36]. However, the species resources of parasitoids of flower-like galls still lack systematic and comprehensive research in Northern Xinjiang.

Based on the information presented above, although our preliminary studies have found that more than one type of flower-like galls exist on Haloxylon, the research on indigenous gall inducers and their biological control is still in the preliminary stage. It is important to understand that the major pest species and their native natural enemy communities are essential for the further development of IPM program. Thus, the present study was conducted to evaluate the occurrence and infestation level of flower-like galls on Haloxylon and to determine the species and biological characteristics of the gall inducers and their parasitoids. The results may provide valuable information for the management and protection of the desert vegetation dominated by Haloxylon.

\section{Materials and Methods}

\subsection{Study Sites and Sampling Collections}

Two collection sites (Table 1) with saxaul trees naturally infested with galls were established to study the biological properties of the gall inducers and their parasitoids in Fukang city, Xinjiang, China, in 2018. Flower-like galls on H. ammodendron were surveyed in site 1 (S1), and on H. persicum in site 2 (S2). A five-point sampling method was used, as follows: three trees with heights of approximately 1-2 $\mathrm{m}$ were selected randomly from five sub-samples of trees from April to October. The number of fresh galls was counted. Then, 70-90 galls were randomly collected and taken to the laboratory for feeding and dissection.

\subsection{Laboratory Rearing of the Galls}

The field-collected galls were placed individually in glass vials (diameter $1.5 \mathrm{~cm}$ and length $10.0 \mathrm{~cm}$ ) to monitor their development in the insect laboratory of the College of Life Sciences and Technology, Xinjiang University (ICXU). The galls were reared in controlled- 
climate chambers under four different temperatures $\left(20,26,32\right.$, and $\left.38{ }^{\circ} \mathrm{C}\right)$ at $65 \pm 5 \%$ $\mathrm{RH}$, with natural and fluorescent lighting of approximately 14:10 h (L:D), from April to October 2018.

Table 1. Survey sites of Haloxylon in Fukang in 2018.

\begin{tabular}{|c|c|c|c|c|c|c|}
\hline Study Site & Coordinates & $\begin{array}{l}\text { Altitude } \\
\text { (m) }\end{array}$ & Habitat Type & $\begin{array}{l}\text { Sampling } \\
\text { Areas }\left(\mathrm{m}^{3}\right)\end{array}$ & $\begin{array}{c}\text { Main } \\
\text { Vegetation }\end{array}$ & Gall Collected \\
\hline $\begin{array}{l}\text { S1: Beishawo Desert } \\
\text { of Fukang city } \\
\text { in Xinjiang }\end{array}$ & $\begin{array}{c}\text { E } 87^{\circ} 53^{\prime} 6^{\prime \prime} \\
\mathrm{N} 44^{\circ} 22^{\prime} 26^{\prime \prime}\end{array}$ & 374 & $\begin{array}{c}\text { Saline-alkali } \\
\text { desertification }\end{array}$ & 100 & $\begin{array}{c}\text { Haloxylon } \\
\text { Halimodendron } \\
\text { Alhagi } \\
\text { Salsola } \\
\text { Tamarix }\end{array}$ & $\begin{array}{l}\text { Flower-like galls of } \\
\text { H. ammodendron, } \\
\text { Flower bud-like galls } \\
\text { of } H \text {. ammodendron }\end{array}$ \\
\hline $\begin{array}{l}\text { S2: Fukang National } \\
\text { Field Scientific } \\
\text { Observation and } \\
\text { Research Station for } \\
\text { Desert Ecosystems } \\
\text { in Xinjiang }\end{array}$ & $\begin{array}{l}\text { E } 87^{\circ} 55^{\prime} 45^{\prime \prime} \\
\mathrm{N} 44^{\circ} 22^{\prime} 0^{\prime \prime}\end{array}$ & 408 & $\begin{array}{c}\text { Saline-alkali } \\
\text { desertification }\end{array}$ & 100 & $\begin{array}{l}\text { Haloxylon } \\
\text { Halimodendron } \\
\text { Salsola } \\
\text { Tamarix }\end{array}$ & $\begin{array}{l}\text { Flower-like galls } \\
\text { of } H \text {. persicum }\end{array}$ \\
\hline
\end{tabular}

The galls were checked every day and the emergence of gall inducers and the corresponding parasitoid adults were recorded and separated according to their taxa and sex. Sex ratio was further calculated as the mean percentage of female offspring for each type of parasitoid from the pest species that emerged in the laboratory. The emerged gall inducers and the corresponding parasitoids were reared in glass vials (diameter $1.5 \mathrm{~cm}$ and length $10.0 \mathrm{~cm}$ ) with gauze. The gall inducers and parasitoids were fed with absorbent cotton soaked with water and $15 \%$ honey water, respectively. The lifespans of gall inducers and parasitoids were recorded every day until they all died. The dead gall inducers and parasitoids were stored in $100 \%$ ethanol for future identification.

\subsection{Identification of Gall Inducers and Parasitoids}

All specimens were maintained in $100 \%$ ethanol and subsequently air dried. Morphological terminology of gall inducers follows the taxonomic literature of Loginova and Parfentiev [19,20] and Li et al. [9], and morphological terminology of parasitoids follows the taxonomic identification keys by Noyes and Hayat [37] and Gibson et al. [38]. The parasitoids were first identified to the family level and then to the genus level. Then, the selected specimens of each morphospecies of parasitoids were identified by S. V. Triapitsyn, a professional taxonomist focusing on several families of Chalcidoidea at the Entomology Research Museum, University of California, Riverside, CA, USA (UCRC). All the specimens were deposited in ICXU.

Molecular analyses for the gall inducers and parasitoids were performed to confirm some morphological identification, and also to determine the correspondence between the gall inducers and parasitoids of the flower-like galls on Haloxylon. Genomic DNA was extracted following the method of Muhetaier et al. [39], and the barcode region of the cytochrome oxidase I (COI) gene was amplified using PCR primers for Psyllids C1J1709 and HCO2198. The PCR primer FWPTF1 and Lep-R1 worked well for wasps [40]. The PCR primer 28sF3633 (5'-TACCGTGAGGGAAAGTTGAAA-3') and 28sR4076 (5' AGACTCCTTGGTCCGTGTTT-3') were used to amplify the D2 domain of 28S (28SD2) nuclear ribosomal DNA (rDNA) [41]. The PCR was performed in a $25 \mu \mathrm{L}$ reaction volume: $2 \mu \mathrm{L}$ of DNA, $8.5 \mu \mathrm{L}$ molecular grade water, $1 \mu \mathrm{L}$ of each primer $(0.3 \mu \mathrm{M}$ each $), 12.5 \mu \mathrm{L}$ $2 \times$ Taq Master Mix (Dye Plus) (Vazyme, Nanjing, China). The thermocycling conditions followed that of Triapitsyn et al. [42] and Morse et al. [43].

Amplification was confirmed by gel electrophoresis and PCR products were used for direct sequencing in both directions at Sangon Biotech Company, Shanghai, China. The sequences were compared to those in the GenBank database using the Basic Local Alignment Search Tool (http:/ / www.ncbi.nlm.nih.gov / BLAST accessed on 15 June 2021). 
All sequences that showed a similarity score lower than $99 \%$ were lodged in the GenBank database. All residual DNA was archived in ICXU.

\subsection{Parasitization Indexes and Eclosion Rates of Parasitoids in Flower-like Galls of Haloxylon}

The number of gall inducers and parasitoids from the flower-like galls were recorded after they were dissected. The parasitization indexes and eclosion rate of the parasitoids were also determined. The parasitization indexes for each parasitoid species included the following [44]: (1) discovery efficiency (DE) which was calculated as (the number of flowerlike galls with parasitoids/the number of collected flower-like galls) $\times 100$, (2) exploitation efficiency (EE) which describes the ability of parasitoids to exploit the gall-inducers. It was calculated as (the number of parasitized gall-inducers in the flower-like galls/the total number of the gall inducers and parasitoid in the parasitized flower-like galls) $\times 100$, (3) parasitoid impact (PI) which describes the efficacy of a parasitoid in reducing the gall inducers. It was calculated as (the number of parasitoids in flower-like galls/the total number of gall inducers and parasitoid in the flower-like galls) $\times 100$, and (4) relative importance (RI) [45] was determined using the following formula: $\mathrm{RI}=[$ (the number of flower-like galls with parasitoids/the number of collected flower-like galls) $\times$ (the number of parasitoids in flower-like galls/total number of gall inducers and parasitoids in the flower-like galls)] $\times 100$ (RI $>10$ was considered "very frequent"; $9.99 \geq \mathrm{RI}>1.0$ was considered "frequent"; $1 \geq \mathrm{RI} \geq 0.09$ was considered "scarce or occasional species" and $\mathrm{RI}<0.09$ was considered "rare"). The eclosion rate was calculated as (the number of parasitoids which emerged from flower-like galls/the total number of gall inducers parasitized by the same parasitoids in the same flower-like galls) $\times 100$.

\subsection{Statistical Analysis}

All analyses were performed using Prism 8.0 (Graphpad Software, San Diego, CA, USA) and assessed for normality (Shapiro-Wilk test) and variance, when appropriate. Sample sizes were chosen according to standard practice in the field. A two-tailed Student's $t$ test was used to determine statistical significance between two groups. For multiple comparisons, one-way ANOVA followed by Tukey's post-test was used. The significance level was set at $p<0.05$. Data are indicated as mean \pm S.E.M of at least three independent experiments.

\section{Results}

\subsection{The Occurrence of Flower-like Galls of Haloxylon}

Three types of flower-like galls were recorded on Haloxylon through the field surveys. The first type was recorded on H. ammodendron and was characterized by bracts that unfolded like a flower. The second type was a flower bud-like gall which was also recorded on $H$. ammodendron. It was characterized by pink and yellow-green bracts that did not unfold. The third type was a flower-like gall recorded on H. persicum (Figure 2a). It was smaller than the flower-like gall recorded on H. ammodendron and was characterized by pale green bracts with slightly pink tips that spread like flowers. The galls occurred twice a year; the first period was from late April to late June, and the second period was from early July to mid-September. The galls dried up after aging, appearing dark brown or yellowish-brown. The occurrence of all the flower-like galls in the succeeding generation was higher than that in the initial generation. The maximum number of the second generation of flower-like galls on $H$. ammodendron was recorded in mid-July (averaging 84 galls per tree), and that of flower bud-like galls on H. ammodendron and flower-like galls on H. persicum were recorded in early August (averaging 168 galls and 33 galls per tree, respectively) (Figure 2b). 
(a)
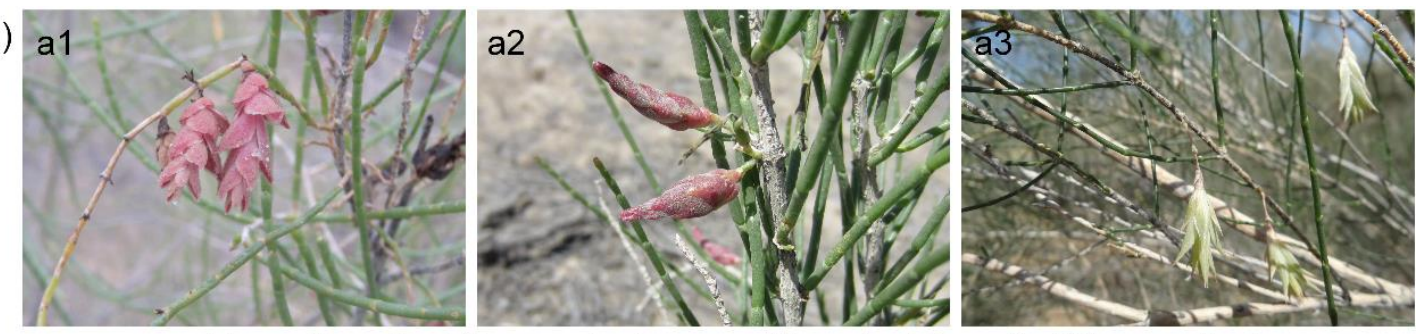

(b)

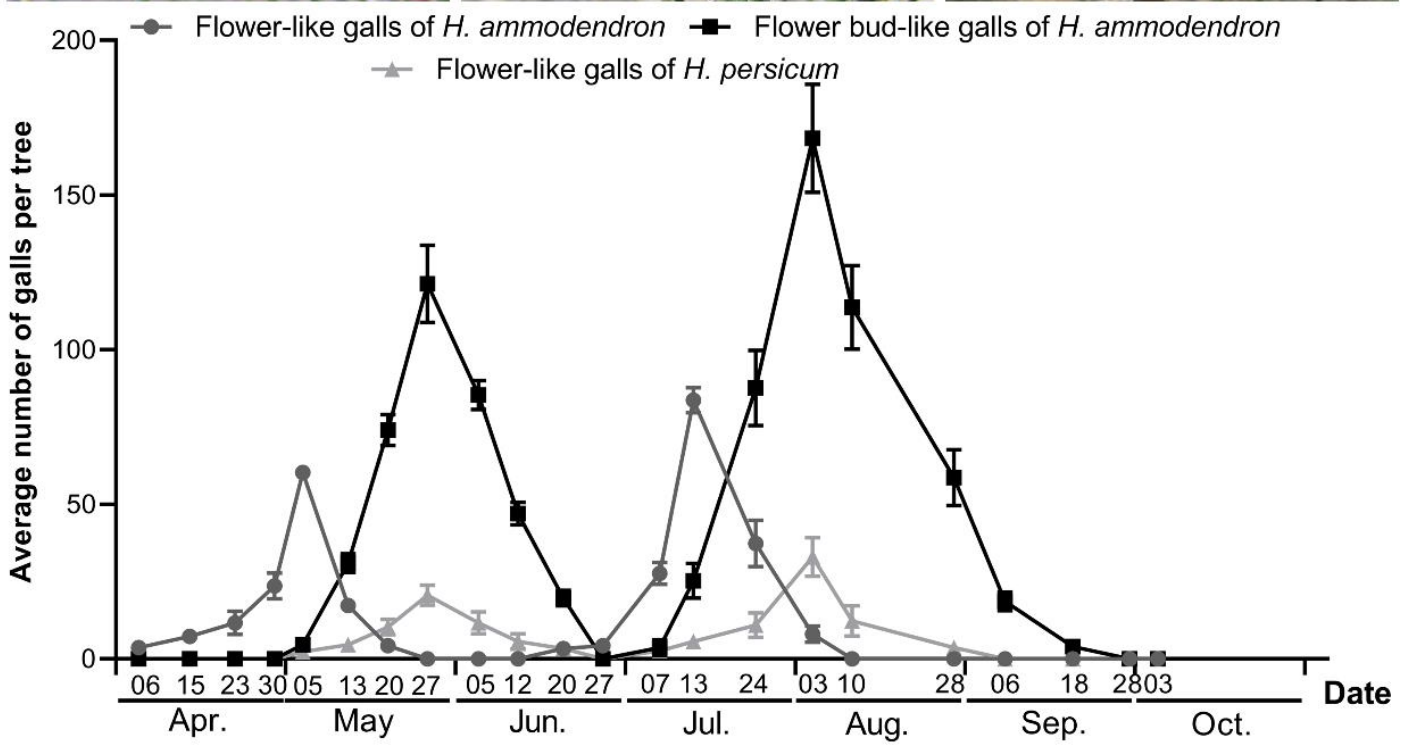

Figure 2. The types (a) and occurrence (b) of flower-like galls on Haloxylon in Fukang, Xinjiang. (a1) The flower-like gall on H. ammodendron; (a2) The flower bud-like gall on H. ammodendron; (a3) The flower-like gall on H. persicum.

\subsection{Species of Gall Inducers and Parasitoids of Flower-like Galls on Haloxylon}

A total of 843 (the number of flower-like galls and flower bud-like galls of H. ammodendron) and 286 (the number of flower-like galls of H. persicum) of flower-like galls on Haloxylon were collected, respectively, at the two sites (S1 and S2) surveyed in 2018 in Fukang. Five species of gall inducers of the genus Caillardia (Hemiptera: Aphalaridae), were recorded from the flowerlike galls on Haloxylon. Caillardia anabasidis and C. azurea were recorded from the flower-like galls on $H$. ammodendron, C. robusta, and C. nana were recorded from the flower bud-like galls on $H$. ammodendron, and only C. notata was recorded from the flower-like galls of $H$. persicum (Table 2). All psyllid species were mostly bivoltine, and they overwintered at the adult stage in the dead grass or the bark of the Haloxylon.

Three species of parasitoids of the genus Psyllaephagus (Hymenoptera: Encyrtidae), were recorded from the flower-like galls on Haloxylon (Table 2). All were solitary koinobiont primary nymphal endoparasitoids of Caillardia spp. P. caillardiae, P. longiventris, and P. ogazae were recorded from both flower-like galls and flower bud-like galls on $\mathrm{H}$. ammodendron. The number of P. ogazae recorded from the flower bud-like galls of H. ammodendron ( $\$ 530^{\prime} 54$ ) was higher than that recorded from the flower-like galls on H. ammodendron ( $\left.\$ 1 \sigma^{\top} 0\right)$. However, only P. caillardiae and P. longiventris were recorded from the flower-like galls on H. persicum. Their numbers were lower than in the galls on H. ammodendron. In addition, the number of female wasps was slightly higher than that of the male wasps of each species of parasitoids emerging from the corresponding galls.

\subsection{Parasitization Indexes of Parasitoids Recorded from Flower-like Galls on Haloxylon}

The different parameters of parasitization (discovery efficiency, exploitation efficiency, parasitoid impact, and relative importance) are given in Table 3 . There were differences among all the parasitization indexes of the parasitoids. Overall, all the parasitization indexes of $P$. caillardiae were significantly higher than that of $P$. ogazae $(\mathrm{F}=4.019, p=0.0280)$ 
and P. longiventris ( $p=0.0072$ ). The parasitoid impact and relative importance of $P$. caillardiae were $32.74 \%$ and 10.04 , respectively. The relative importance of $P$. caillardiae peaked at $44.44 \%$ (in flower bud-like galls of H. ammodendron collected on 24 July), that of P. ogazae was $21.49 \%$ (in flower bud-like galls of $H$. ammodendron collected on 28 August) and that of $P$. longiventris was $11.11 \%$ (in flower bud-like galls of $H$. ammodendron collected on 24 July). The results indicated that $P$. caillardiae was the dominant parasitoid of flower-like galls on Haloxylon.

\subsection{Effect of Temperature on the Emergence of Parasitoids from Flower-like Galls on Haloxylon}

The number of emerged parasitoids from the flower bud-like galls was the highest $\left(\$ 125 \sigma^{\top 112}\right)$ among the three types of flower-like galls. The number of emerged parasitoids from the flower-like galls peaked at $26^{\circ} \mathrm{C}\left(\$ 710^{\top} 68\right)$ and lowered at $38^{\circ} \mathrm{C}\left(\% 21 \circ^{\top} 18\right)$ (Figure 3a). The parasitoids recovered from flower-like galls of $H$. ammodendron emerged earlier than that from other flower-like galls; P. caillardiae emerged earlier than P. ogazae, which rarely emerged from other flower-like galls, but from the flower bud-like galls of H. ammodendron (Figure 3a,b and Figure 4). The emergence rate of parasitoids recovered from flower-like galls of Haloxylon showed a rising tendency at first and then decreased with an increase in temperature from $20^{\circ} \mathrm{C}$ to $38^{\circ} \mathrm{C}$. The highest eclosion rate was recorded at $26{ }^{\circ} \mathrm{C}$, and the minimum at $38^{\circ} \mathrm{C}$ (Figure $3 \mathrm{~b}$ ). The eclosion rate of parasitoids recovered from flower bud-like galls of $H$. ammodendron was the highest compared to that of parasitoids from the other two types of flower-like galls. The optimum temperature for eclosion was between $26{ }^{\circ} \mathrm{C}$ and $32^{\circ} \mathrm{C}$.

\subsection{Effect of Temperature on the Lifespans of Adult Parasitoids Recovered from the Flower-like Galls on Haloxylon}

The lifespans of the three species of Psyllaephagus showed differences, and they were affected by temperature and the type of flower-like galls (Figure 4). The lifespans of adult parasitoids that emerged from flower-like galls on Haloxylon showed a shortened trend with an increase in temperature. The lowest number and the shortest lifespan (less than five days) of parasitoids were recorded at $38^{\circ} \mathrm{C}$. The average lifespans expectancy of P. caillardiae and P. ogazae at $20^{\circ} \mathrm{C}$ were 36.64 days and 25.79 days, respectively. They were, respectively, 1.46 days and 1.81 days at $38^{\circ} \mathrm{C}$. The average lifespan of P. longiventris at $20^{\circ} \mathrm{C}$ was 28.94 days. When the temperature rose to $38^{\circ} \mathrm{C}$, no living P. longiventris was observed.

Moreover, the females of the three species of Psyllaephagus recorded from flower-like galls on Haloxylon had longer lifespans than males at $20^{\circ} \mathrm{C}$, except for P. longiventris that emerged from the flower-like galls on $H$. ammodendron and P. ogazae that emerged from the flower bud-like galls on $H$. ammodendron. The lifespan of female P. caillardiae recorded from the flower-like galls on $H$. ammodendron, was longer than that of female P. longiventris at all the given temperatures. The lifespan of female $P$. longiventris, recorded from the flower bud-like galls on $H$. ammodendron at $20^{\circ} \mathrm{C}$, was significantly longer than that of males $\left(\chi^{2}=11.20, p=0.0389\right)$. However, there were no significant differences in lifespans between female and male P. ogazae or P. caillardiae which were recorded from the flower-like galls on $H$. ammodendron at all the temperatures. Only female P. longiventris emerged from the flower-like galls on $H$. persicum. However, there were no significant differences in lifespans between females and males of each parasitoid species from flower-like galls on $H$. persicum at all temperatures (Figure 4 ).

\subsection{Gall Inducers and Parasitoid Species Characterization}

Molecular analyses confirmed the identity of gall inducers and parasitoids that emerged from the flower-like galls on Haloxylon. Since sequences of five species of Caillardia and three species of Psyllaephagus were not present in the GenBank database, all sequences obtained from specimens identified by the morphological analysis were deposited into the GenBank database (Table 4). A total of 33 sequences were obtained. These included the CO1 and 28S sequences of Caillardia, except that of CO1 of C. nana. For Psyllaephagus caillardiae only the CO1 sequence was obtained, but none from the other two wasps. 
Table 2. Parasitoids and their hosts of flower-like galls on Haloxylon in 2018.

\begin{tabular}{|c|c|c|c|c|c|c|c|c|c|}
\hline Type of Galls & $\begin{array}{c}\text { Gall Inducers } \\
\text { (Number of Adults) }\end{array}$ & $\begin{array}{c}\text { Parasitoids } \\
\text { (Number of Adults } \\
\text { and Sex Ratio) }\end{array}$ & $\begin{array}{l}\text { Generation of } \\
\text { Gall Inducers }\end{array}$ & $\begin{array}{l}\text { Overwintering } \\
\text { Mode of Gall } \\
\text { Inducers }\end{array}$ & $\begin{array}{c}\text { Host Stage } \\
\text { Attacked (Instar) }\end{array}$ & $\begin{array}{l}\text { Habit of } \\
\text { Parasitoids }\end{array}$ & $\begin{array}{l}\text { Deworming } \\
\text { State (Host) }\end{array}$ & $\begin{array}{l}\text { Deworming State } \\
\text { (Parasitoid) }\end{array}$ & Identifier \\
\hline $\begin{array}{l}\text { Flower-like galls of } \\
\text { H. ammodendron }\end{array}$ & $\begin{array}{l}\text { C.anabasidis (146) } \\
\text { C. azurea (58) }\end{array}$ & $\begin{array}{l}\text { P. caillardiae }\left(\$ 47 \sigma^{\top} 35\right) \\
\text { P. ogazae }\left(\$ 1 \sigma^{\top} 0\right) \\
\text { P. longiventris }\left(\$ 14 \sigma^{\top} 9\right)\end{array}$ & 2 & $\begin{array}{l}\text { Adults in the dead } \\
\text { grass or the bark of } \\
\text { the H. ammodendron }\end{array}$ & Nymph (III, IV) & $\begin{array}{l}\text { Primary, solitary, } \\
\text { endoparasitoid }\end{array}$ & Nymph & Adult & $\begin{array}{l}\text { S.V. Triapitsyn } \\
\text { and H.-Y. Hu }\end{array}$ \\
\hline $\begin{array}{l}\text { Flower bud-like galls of } \\
\text { H. ammodendron }\end{array}$ & $\begin{array}{l}\text { C. robusta (12) } \\
\text { C. nana (189) }\end{array}$ & $\begin{array}{l}\text { P. caillardiae }\left(\$ 680^{\top} 56\right) \\
\text { P. ogazae }\left(\$ 530^{\prime} 54\right) \\
\text { P. longiventris }\left(\$ 40^{\prime} 2\right)\end{array}$ & 2 & $\begin{array}{l}\text { Adults in the dead } \\
\text { grass or the bark of } \\
\text { the H. ammodendron }\end{array}$ & Nymph (III, IV) & $\begin{array}{l}\text { Primary, solitary, } \\
\text { endoparasitoid }\end{array}$ & Nymph & Adult & $\begin{array}{l}\text { S.V. Triapitsyn } \\
\text { and H.-Y. Hu }\end{array}$ \\
\hline $\begin{array}{c}\text { Flower-like galls of } \\
\text { H. persicum }\end{array}$ & C. notata (161) & $\begin{array}{l}\text { P. caillardiae }\left(\$ 32 \sigma^{\top} 14\right) \\
\text { P. longiventris }\left(\$ 150^{\top} 0\right)\end{array}$ & 2 & $\begin{array}{l}\text { Adults in the dead } \\
\text { grass or the bark of } \\
\text { the H. persicum }\end{array}$ & Nymph (IV) & $\begin{array}{l}\text { Primary, solitary, } \\
\text { endoparasitoid }\end{array}$ & Nymph & Adult & $\begin{array}{l}\text { S.V. Triapitsyn } \\
\text { and H.-Y. Hu }\end{array}$ \\
\hline
\end{tabular}

Table 3. Parasitization indexes and relative importance of the parasitoid species of flower-like galls on Haloxylon.

\begin{tabular}{|c|c|c|c|c|c|c|c|c|c|c|c|c|c|}
\hline \multirow{2}{*}{ Temperature } & \multirow{2}{*}{ Date } & \multicolumn{4}{|c|}{ Psyllaephagus caillardiae } & \multicolumn{4}{|c|}{ Psyllaephagus ogazae } & \multicolumn{4}{|c|}{ Psyllaephagus longiventris } \\
\hline & & DE & EE & PI & RI & DE & EE & PI & RI & $\mathrm{DE}$ & EE & PI & RI \\
\hline \multirow{5}{*}{$\begin{array}{l}\text { Flower-like galls of } \\
\text { H. ammodendron }\end{array}$} & 07/July/2018 & 23.38 & 96.67 & 18.81 & $4.61(\mathrm{~F})$ & 1 & 1 & 1 & 1 & 6.25 & 50.00 & 1.76 & $0.60(S)$ \\
\hline & 13/July/2018 & 54.29 & 74.69 & 40.87 & 22.89(VF) & 0.72 & 25.00 & 0.48 & $0.01(\mathrm{~S})$ & 12.14 & 82.64 & 10.03 & $1.34(\mathrm{~F})$ \\
\hline & 24/July/2018 & 35.19 & 95.83 & 34.33 & $12.08(\mathrm{VF})$ & 7.41 & 100 & 5.97 & $0.44(\mathrm{~S})$ & 11.11 & 100.00 & 8.96 & $1.00(\mathrm{~S})$ \\
\hline & 03/August/2018 & 16.67 & 100.00 & 16.67 & $2.78(\mathrm{~F})$ & 16.67 & 100.00 & 16.67 & $2.78(\mathrm{~F})$ & / & / & / & / \\
\hline & Total & 32.38 & 91.80 & 27.67 & 10.59(VF) & 8.27 & 75.00 & 7.71 & $1.08(\mathrm{~F})$ & 9.83 & 77.55 & 6.92 & $0.98(S)$ \\
\hline \multirow{6}{*}{$\begin{array}{c}\text { Flower bud-like galls of } \\
\text { H. ammodendron }\end{array}$} & 24/July/2018 & 66.67 & 100.00 & 66.67 & 44.44(VF) & / & / & / & / & 33.33 & 100.00 & 33.33 & 11.11(VF) \\
\hline & 03/August/2018 & 1.67 & 16.67 & 7.14 & $0.48(S)$ & 1.67 & 16.67 & 3.13 & $0.21(\mathrm{~S})$ & 4.17 & 25.00 & 7.81 & $1.30(\mathrm{~F})$ \\
\hline & 10/August/2018 & 32.58 & 75.76 & 26.38 & $9.21(\mathrm{~F})$ & 28.57 & 57.61 & 20.08 & $7.3(\mathrm{~F})$ & / & / & / & / \\
\hline & 18/August/2018 & 58.97 & 100.00 & 59.80 & 36.54(VF) & 16.67 & 75.00 & 16.49 & $3.80 \mathrm{~F})$ & 1.28 & 25.00 & 1.28 & $0.07(\mathrm{R})$ \\
\hline & 28/August/2018 & 23.89 & 100.00 & 24.16 & 6.37(F) & 44.97 & 100.00 & 44.97 & 21.49(VF) & 0.89 & 25.00 & 0.89 & $0.03(\mathrm{R})$ \\
\hline & Total & 36.76 & 78.49 & 36.83 & 19.41(VF) & 22.97 & 62.32 & 21.17 & $8.21(\mathrm{~F})$ & 9.92 & 43.75 & 10.83 & $3.13(\mathrm{~F})$ \\
\hline \multirow{4}{*}{$\begin{array}{l}\text { Flower-like gall of } \\
\text { H. persicum }\end{array}$} & 24/July/2018 & 20.00 & 100.00 & 20.00 & $0.04(\mathrm{R})$ & l & / & l & / & 11.67 & 100.00 & 11.67 & $0.01(\mathrm{R})$ \\
\hline & 03/August/2018 & 25.73 & 100.00 & 25.73 & $0.07(\mathrm{R})$ & / & / & / & / & 10.54 & 100.00 & 10.54 & $0.01(\mathrm{R})$ \\
\hline & 11/August/2018 & 54.63 & 98.53 & 55.47 & $0.30(\mathrm{~S})$ & / & / & / & / & 7.41 & 50.00 & 6.67 & $0.01(\mathrm{R})$ \\
\hline & Total & 33.45 & 99.51 & 33.73 & $0.14(\mathrm{~S})$ & / & / & / & / & 9.87 & 83.33 & 9.63 & $0.01(\mathrm{R})$ \\
\hline
\end{tabular}

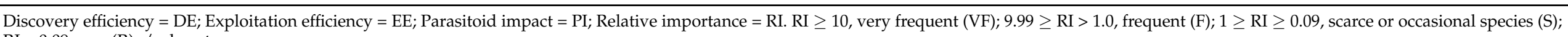

$\mathrm{RI}<0.09$, rare (R); /, absent. 


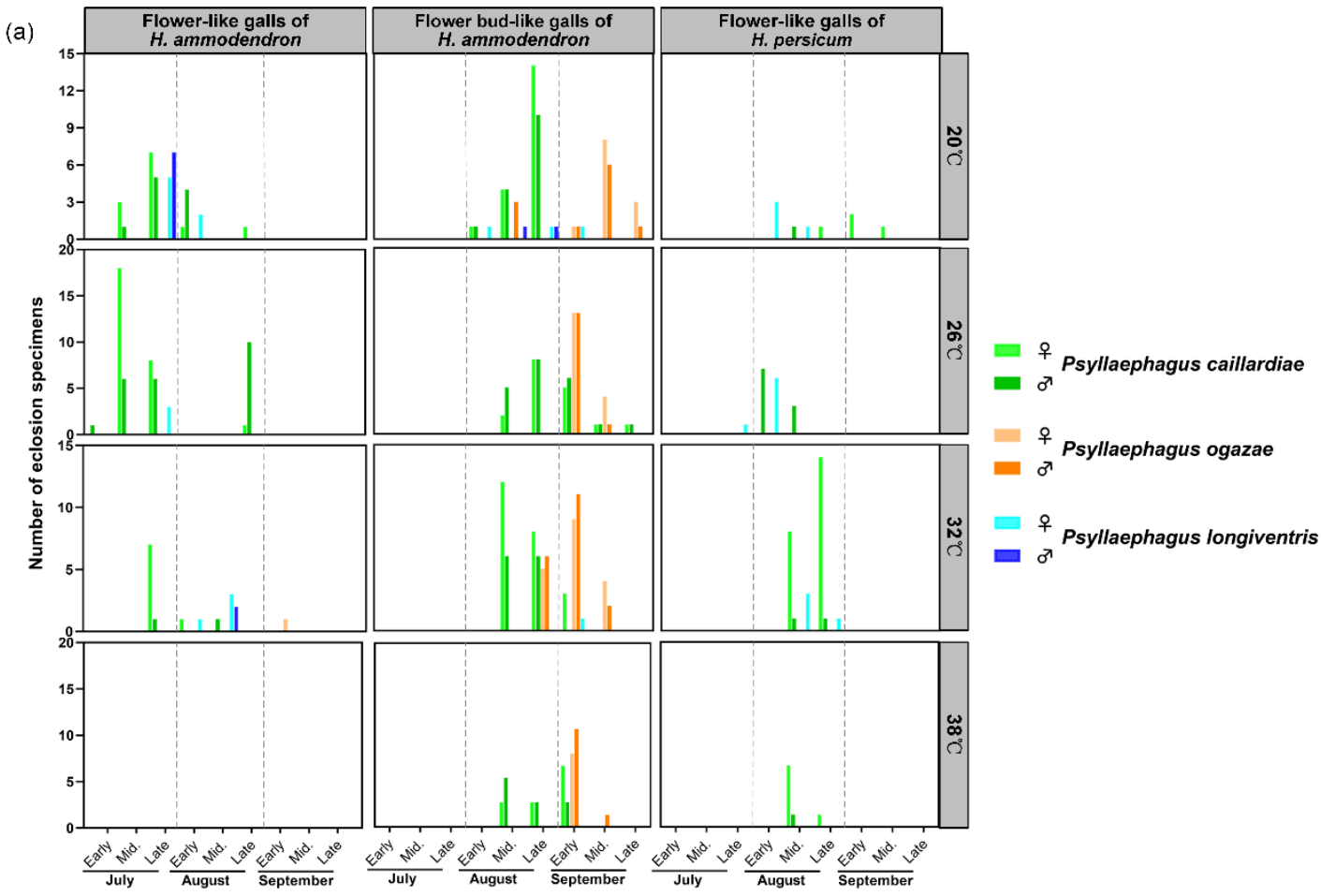

(b)

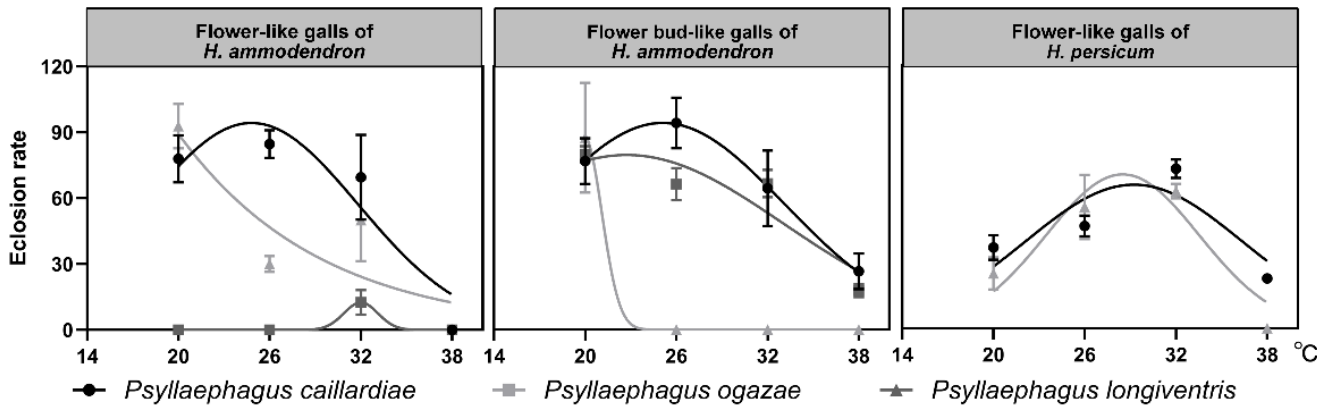

Figure 3. Emergence periods (a) and emergence rate effects (b) of parasitoids of flower-like galls on Haloxylon at four different temperatures of $20,26,32$, and $38{ }^{\circ} \mathrm{C}$. The emergence of individuals from flower-like galls was investigated daily under lab conditions in Fukang, China. Midpoints mean the average value. The regression line shows the trend of emergence rate with temperature. 

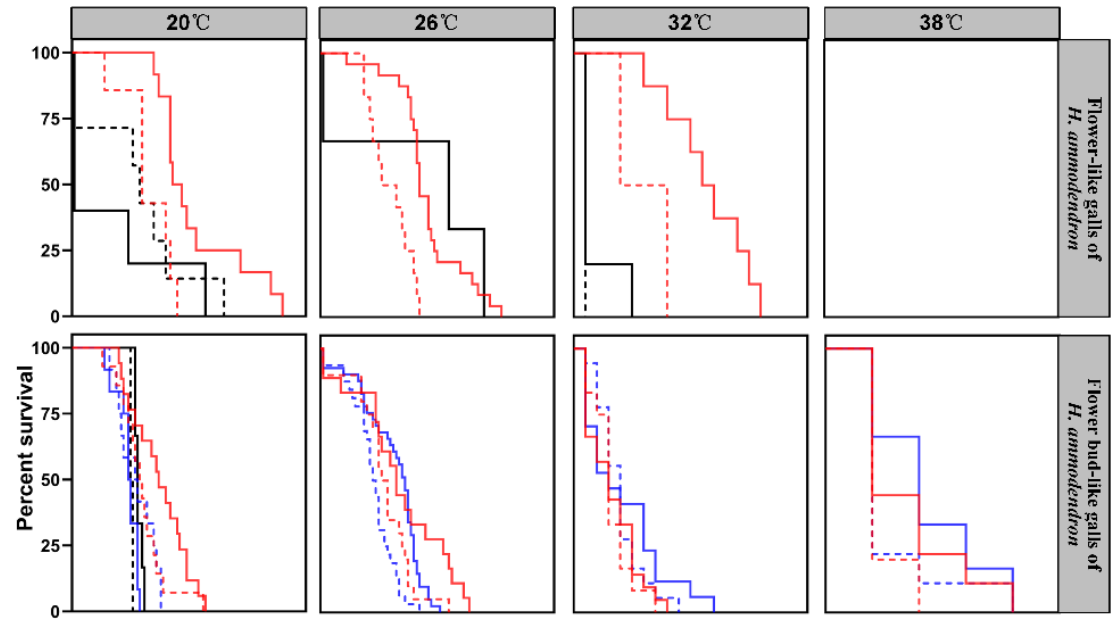

- Psyllaephagus caillardiae
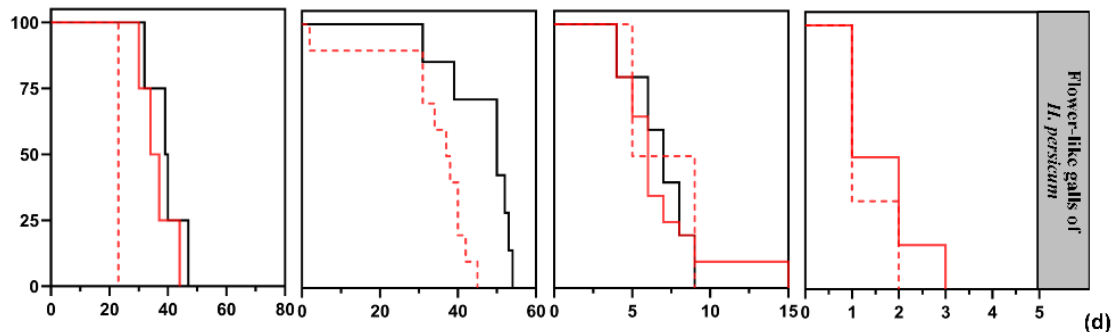

- Psyllaephagus ogazae

- Psyllaephagus longiventris

- famales

-.. males

Figure 4. Survival curves of parasitoids of flower-like galls on Haloxylon at four different temperatures of $20,26,32$, and $38^{\circ} \mathrm{C}$.

Table 4. Sampling information and GenBank accession number for the deposited sequences generated from this study.

\begin{tabular}{|c|c|c|c|c|c|}
\hline Species & $\begin{array}{l}\text { No. Identified } \\
\text { by Molecu- } \\
\text { lar Methods }\end{array}$ & Sex & Associated Host & $\begin{array}{l}\text { CO1 GenBank } \\
\text { Accession No. }\end{array}$ & $\begin{array}{l}\text { 28S GenBank } \\
\text { Accession No. }\end{array}$ \\
\hline P. caillardiae & 3 & $10^{7} 29$ & $\begin{array}{l}\text { Flower-like galls } H \text {. ammodendron } \\
\text { Flower bud-like galls of H. ammodendron }\end{array}$ & $\begin{array}{l}\text { MZ436006 } \\
\text { MZ438311 }\end{array}$ & $\begin{array}{l}\text { MZ436078 } \\
\text { MZ469911 } \\
\text { MZ469912 }\end{array}$ \\
\hline P. ogazae & 4 & $20^{7} 2 q$ & Flower bud-like galls of $H$. ammodendron & / & $\begin{array}{l}\text { MZ436075 } \\
\text { MZ469916 } \\
\text { MZ469909 } \\
\text { MZ469905 }\end{array}$ \\
\hline P. longiventris & 3 & $10^{\top} 29$ & Flower-like galls of $H$. persicum & / & $\begin{array}{l}\text { MZ436079 } \\
\text { MZ469917 }\end{array}$ \\
\hline C. anabasidis & 3 & $20^{\top} 19$ & Flower-like galls H. ammodendron & $\begin{array}{l}\text { MZ436072 } \\
\text { MZ437083 }\end{array}$ & $\begin{array}{l}\text { MZ436073 } \\
\text { MZ469908 } \\
\text { MZ469903 }\end{array}$ \\
\hline C. azurea & 3 & $20^{\top} 19$ & Flower-like galls H. ammodendron & $\begin{array}{l}\text { MZ436003 } \\
\text { MZ437085 } \\
\text { MZ438310 }\end{array}$ & $\begin{array}{l}\text { MZ436076 } \\
\text { MZ469907 }\end{array}$ \\
\hline C. robusta & 4 & $10^{\top 3} 3 q$ & Flower bud-like galls of $H$. ammodendron & MZ436005 & $\begin{array}{l}\text { MZ436077 } \\
\text { MZ469915 } \\
\text { MZ469904 }\end{array}$ \\
\hline C. nana & 3 & $20^{\top} 19$ & Flower bud-like galls of $H$. ammodendron & / & $\begin{array}{l}\text { MZ436074 } \\
\text { MZ469914 } \\
\text { MZ469910 }\end{array}$ \\
\hline C. notate & 5 & $30^{7} 29$ & Flower-like galls of $H$. persicum & MZ436004 & $\begin{array}{l}\text { MZ436080 } \\
\text { MZ469906 } \\
\text { MZ469913 }\end{array}$ \\
\hline
\end{tabular}




\section{Discussion}

In this study, we found that the galls on the Haloxylon spp. could be divided into three types. The galls of $H$. ammodendron especially could be divided into flower-like galls and flower-bud like galls based on whether their bracts expanded or not. The present study indicated that the three types of flower-like galls on the Haloxylon spp. were associated with different gall inducers, all of which belonged to the genus Caillardia. Moreover, the gall inducers of the flower-like galls and flower bud-like galls, which were two similar kinds of flower-like galls on the same saxaul plant species, were also different. However, a previous study reported that flower-like galls and flower bud-like galls on $H$. ammodendron were grouped into the same category, and four psyllid species (C. robusta, C. azurea, C. nana, and C. notata) were the inducers of these galls on H. ammodendron [9]. In addition, our study demonstrated that $C$. notata was the only inducer of flower-like galls on H. persicum. This is consistent with the result of the previous study [9].

Psyllid is a kind of sucking insect highly dependent on its host [11-17]. Many gall inducers in Psylloidea are highly host-specific and occur in all of the currently recognized families [46-49]. In present study, only species of Caillardia induced galls with multiple flower-like scales on H. ammodendron and H. persicum, while they were reported as gall inducers on Haloxylon spp. previously [18-23]. Interestingly, two psyllids species shared the same type of galls on H. ammodendron sympatrically, although different psyllid species coexisting on the same host plant usually used at least slightly different ecological niches [50]. Based on the numerical superiority and degree of damage of $C$. anabasidis and C. nana, we suggested that they were dominant gall inducers of the flower-like galls and flower bud-like galls, respectively.

Due to the very distinct sexual dimorphism of Caillardia spp. and slight morphological differences among three species of Psyllaephagus spp., it was difficult to identify the species only by morphological characters. As such, determining their species identities using genetic analyses was identified as one of the priorities within a study with broader sampling $[51,52]$. As a routine procedure, all species reared from different galls were accurately identified by the combination of both molecular and morphological characters. The consequence suggested that DNA barcoding of $\mathrm{CO} 1$ and $28 \mathrm{~S}$ specific fragments was feasible for the rapid identification of Caillardia and Psyllaephagus. However, the corresponding relationships between gall inducers and their parasitoids remain to be determined.

Generally, parasitization indexes were widely used to evaluate the parasitic efficacy of egg parasitoids $[45,53]$. In this study, we applied the indexes to evaluate the overall efficiency of nymphal parasitoids from flower-like galls for the first time. Among them, the exploitation efficiency (EE) was higher than the discovery efficiency (DE). In most cases, the EE was $100 \%$ since only one parasitized psyllid was reared from one gall. Flowerlike galls of $H$. ammodendron collected on 13 July and flower bud-like galls collected on 3 August and 10 August had lower EE. A reasonable explanation was that both gall inducers and galls occurred in abundance at these times normally. While some of these galls only contained a non-parasitized gall-inducing psyllid, others contained both parasitoid(s) and psyllid(s). The index, RI, indicated the frequency of parasitoids recorded from the galls, and it was used to determine the dominant parasitoids species from different galls. Our results demonstrated that $P$. caillardiae was the dominant parasitoid of flower-like galls on Haloxylon. However, dissection of the flower-like galls showed that it was difficult for psyllids to develop from young nymphs into adults in laboratory conditions, and also difficult to determine from their external appearances whether young nymphs had been parasitized. This could result in the underestimation of the actual parasitic rate in the wild. Intriguingly, the parasitoid impact (PI) of P. ogaza was the lowest in mid-to-late July, while that of $P$. caillardiae came to the highest during the same periods, indicating that there may be parasitic competition between them.

The results showed that the parasitic period and the eclosion time of the parasitoids were consistent with the occurrence of corresponding galls and the developmental duration of gall inducers and their parasitoids in the three types of flower-like galls. Based on the 
occurrence period of these galls, the parasitic period of $P$. caillardiae was earlier than that of $P$. longiventris, and P. ogazae parasitized last. The emerging period of parasitoids (especially the dominant parasitoid P. caillardiae) coincided with the high incidence of the corresponding galls on Haloxylon. In detail, the period of parasitoids emerged from the flower-like galls of $H$. ammodendron mainly ranged from mid-July to early August, which coincided with the high incidence of the galls in mid-July. However, the parasitic rate of parasitoids was the lowest at the early stage of gall formation than that at other stages. It indicated that the parasitoids attacked the gall inducers most frequently after the early stage of galls formation following the maturation of galls and when the nymph of Caillardia had developed.

The galls provide shelters for the gall inducers and increase the difficulty for the parasitic natural enemies to parasitize in the hosts [54]. Anecdotal evidence suggests that the parasitic rates of wasps decrease with increased gall size, while the eclosion rate of adults increases [55-57]. However, in this study, the parasitic rate (PI) of wasps on H. ammodendron was higher than that on H. persicum, and the eclosion rate showed the opposite, while the size of flower-like galls on $H$. ammodendron was bigger than those on $H$. persicum. The epidermal cells of integument of flower-like galls on H. ammodendron severely damaged by Caillardia spp. resulted in a loose arrangement and the exposure of vascular tissues [58]. Therefore, the flower-like galls were easier to pierce, compared to the severely lignified galls. Meanwhile, our previous study found that the ovipositor length of Psyllaephagus was about $0.39-0.82 \mathrm{~mm}$, making it easier to pierce through the bracts of the galls $(0.49 \pm 0.22 \mathrm{~mm})$ [59]. Nonetheless, it was unclear whether successful parasitism of parasitoid was related to the ovipositor length of parasitoid and the size of flower-like gall on Haloxylon and therefore deserved to be further studied.

Temperature is an important environmental factor that affects the life activities of insects $[60,61]$. The present study demonstrated that the eclosion rate and lifespans of parasitoids changed with an increase in temperature. When the temperature ranged from $20^{\circ} \mathrm{C}$ to $38^{\circ} \mathrm{C}$, the eclosion rate of parasitoids increased first and then decreased, while their lifespans decreased gradually. This was consistent with the report about the composition of Torymus parasitoids found in the galls of chestnut trees and other related studies on parasitoids [62-64]. However, the biological characteristics (eclosion rate, the sex ratio and longevity) of parasitoids were influenced by many other internal factors (female wasp nutrition, egg nutrition, and ovipositing age of female wasps) and external factors (temperature, humidity, and light cycle) $[33,65]$. Therefore, the influences of these factors on the biological characteristics of the parasitoids recorded in this study need to be further evaluated.

Our findings highlight the importance of knowing the biological characteristics of the parasitoids of gall inducers. The results may contribute to an understanding of the need for their conservation and potential application in biological control. However, the parasitoids on Haloxylon were investigated only in native areas where the control efficiency of these gall inducers in Xinjiang was low (the highest parasitic rate was about 36\%). Thus, an effective integrated pest management (IPM) program against the gall inducers remains to be further developed. It is recommended that a more comprehensive survey be conducted to identify more parasitoid species, and to assess the possibility of using these parasitoids to control pests. In addition, the mechanism underlying parasitoids search for their corresponding hosts as well as the nutritional relationships among galls, gall inducers, and parasitoids remain to be further investigated.

Author Contributions: Conceptualization, Q.Z. and H.-Y.H.; Formal analysis, Q.Z., H.-Y.H. and L.-L.J.; Funding acquisition, H.-Y.H.; Investigation, Q.Z., L.-L.J., J.G. and D.-K.Z.; Methodology, Q.Z.; Supervision, H.-Y.H.; Validation, H.-Y.H.; Writing—original draft, Q.Z. and H.-Y.H.; Writingreview \& editing, Q.Z. and H.-Y.H. All authors have read and agreed to the published version of the manuscript. 
Funding: This research was funded by the National Natural Science Foundation of China, grant numbers 31672338 \& U1170305, Tianshan Talent Project of the Xinjiang Uighur Autonomous Region, grant number 10020000220, and the Doctoral Innovation Project of Xinjiang University, grant number XJUBSCX-2017018.

Acknowledgments: We are grateful to S.V. Triapitsyn who is an expert taxonomist on several families of Chalcidoidea and works in the Entomology Research Museum, University of California, Riverside, California, USA (UCRC) for the identification of three Encyrtidae species. We also thank doctoral student Ning Kang (College of Life Science and Technology, Xinjiang University) and Qian Zhao's husband Jiao-Hong Li (Yangzhou University) for editing the manuscript.

Conflicts of Interest: The authors declare no conflict of interest. The funders had no role in the design of the study; in the collection, analyses, or interpretation of data; in the writing of the manuscript, or in the decision to publish the results.

\section{References}

1. Wu, X.; Zheng, X.J.; Li, Y.; Xu, G.Q. Varying responses of two Haloxylon species to extreme drought and groundwater depth. Environ. Exp. Bot. 2019, 158, 63-72. [CrossRef]

2. Buras, A.; Wucherer, W.; Zerbe, S.; Noviskiy, Z.; Muchitdinov, N.; Shimshikov, B.; Zverev, N.; Schmidt, S.; Wilmking, M.; Thevs, N. Allometric variability of Haloxylon species in Central Asia. For. Ecol. Manag. 2012, 274, 1-9. [CrossRef]

3. Jia, Z.G.; Lu, Q.; Guo, B.G.; Zhao, M.; Lang, Y.Q. Progress in the study of psammophyte-Haloxylon. For. Res. 2004, 17, 125-132.

4. Saji, A.; Sakkir, S.; Dhaheri, S.S.A. Galling insects associated with Haloxylon spp. (Bunge) in Abu Dhabi, United Arab Emirates. Int. J. Biodivers. Conserv. 2013, 5, 89-295. [CrossRef]

5. Skuhrava, M.; Karimpour, Y.; Sadeghi, H.; Gol, A.; Joghataie, M. Gall midges (Diptera: Cecidomyiidae) of Iran: Annotated list and zoogeographical analysis. Acta Soc. Zool. Bohem. 2014, 78, 269-301.

6. Slepyan, E.I. Specific characteristics of gall-forming and teratogenic processes on the assimilational shoots of Haloxylon aphyllum and H. persicum Chenopodiaceae Referat. Bot Zhur. 1958, 43, 1595-1607.

7. Mohammadi, M. Phenological relation of the pests associated with saxaul plant in Abardeg area. Iran. J. Range Desert Res. 2003, $10,17-38$.

8. Xue, X.F.; Zhang, J.P.; Li, F.L.; Hong, X.-Y. A new eriophyoid mite species (Acari: Eriophyidae) infesting Haloxylon ammodendron and H. persicum (Chenopodiaceae) in Xinjiang Uigur Autonomous Region, northwest China. Syst. Appl. Acarol 2012, 17, 202-209. [CrossRef]

9. Li, F.L.; Wu, X.h.; Wang, P.L.; Liang, H.J.; Wang, X.; Wang, L.J.; Zhang, J.P. The occurrence regularity of psyllid in Haloxylon spp and its influencing factors. Acta Ecol. Sin. 2012, 32, 2311-2319.

10. Li, F.L.; Li, T.; Su, J.; Yang, S.; Wang, P.L.; Zhang, J.P. Temporal and spatial differences in gall induction on Haloxylon by Aceria haloxylonis (Acari: Eriophyidae) in the Gurbantunggut Desert. Syst. Appl. Acarol 2016, 21, 1670-1680. [CrossRef]

11. Sagar, D.; Balikai, R.A. Psyllid pests of horticultural and forage crops: Taxonomy, biology and their management. J. Exp. Zool. India 2013, 16, 1-18.

12. Geiger, C.A.; Gutierrez, A.R. Ecology of Heteropsylla cubana (Homoptera: Psyllidae): Psyllid damage, tree phenology, thermal relations, and parasitism in the field. Environ. Entomol. 2000, 29, 76-86. [CrossRef]

13. Jarausch, B.; Burckhardt, D.; Lauterer, P.; Jarausch, W. Psyllids (Hemiptera, Psylloidea) captured in commercial apple and stone fruit orchards in southwest Germany, eastern France and northwest Switzerland. Mitt. Schweiz. Entomol. Ges. 2009, 82, 205-215.

14. Hoy, M.A.; Singh, R.; Rogers, M.E. Evaluations of a novel isolate of Isaria fumosorosea for control of the asian citrus psyllid, Diaphorina citri (hemiptera: Psyllidae). Fla. Entomol. 2010, 93, 24-32. [CrossRef]

15. Shivankar, V.J.; Rao, C.N. Psyllids and their management. Pest Manag. Hortic. Ecosyst. 2010, 16, 1-4.

16. Yana, W.; Tamesse, J.L.; Burckhardt, D. Jumping Plant-Lice of the Family Psyllidae Latreille (Hemiptera: Psylloidea) from the Center Region of Cameroon: Faunistics, Phenology and Host Plants. J. Entomol. 2010, 7, 1-18. [CrossRef]

17. Spodek, M.; Burckhardt, D.; Protasov, A.; Mendel, Z. First record of two invasive eucalypt psyllids (Hemiptera: Psylloidea) in Israel. Phytoparasitica 2015, 43, 401-406. [CrossRef]

18. Lashkari, M.; Burckhardt, D.; Manzari, S. First report of ten psyllid species (Hemiptera: Psylloidea) from Kerman province, Iran. J. Entomol. Res. 2016, 8, 223-235.

19. Loginova, M.M.; Parfentiev, V.J. Species of the genus Caillardia Bergevin (Homoptera, Psyllidae) injurious to Haloxylon. Entomol. Obozr. 1956, 35, 377-396.

20. Loginova, M.M. Review of the genus Caillardia Bergevin (Homoptera, Aphalaridae) with descriptions of new species. Tr. Zool. Inst. 1978, 71, 6-22.

21. Spodek, M.; Burckhardt, D.; Freidberg, A. The Psylloidea (Hemiptera) of Israel. Zootaxa 2017, 4276, 301. [CrossRef]

22. Sultanov, R.A.; Danilevich, O.K. Peculiarities of biology of two psyllids species of Caillardia Bergevin genus on the Haloxylon aphyllum (Minkw.) Iljin in southern Kyzylkum. Uzb. Biol. Zh. 1995, 4-5, 62-65.

23. Kaplin, V.G. Complexes of Arthropoda animals inhabiting galls of Haloxylon Psyllidae of genus Caillardia Bergev. in eastern Kara-Kum. Izv. Akad. Nauk Turkm. SSR Ser. Biol. Nauk 1981, 20-27. 
24. Passos, L.C.; Soares, M.A.; Collares, L.J.; Malagoli, I.; Desneux, N.; Carvalho, G.A. Lethal, sublethal and transgenerational effects of insecticides on Macrolophus basicornis, predator of Tuta absoluta. Entomol. Gen. 2018, 38, 127-143. [CrossRef]

25. Soares, M.A.; Campos, M.R.; Passos, L.C.; Carvalho, G.A.; Haro, M.M.; Lavoir, A.V.; Biondi, A.; Zappala, L.; Desneux, N. Botanical insecticide and natural enemies: A potential combination for pest management against Tuta absoluta. J. Pest Sci. 2019, $92,1445$. [CrossRef]

26. Dhawan, A.K.; Singh, S.; Kumar, S. Integrated Pest Management (IPM) helps reduce pesticide load in cotton. J. Agric. Sci. Technol. 2009, 11, 599-611.

27. Daniel, C.; Grunder, J. Integrated management of european cherry fruit fly Rhagoletis cerasi (L.): Situation in Switzerland and Europe. Insects 2012, 3, 956-988. [CrossRef]

28. Chen, H.Y.; Li, H.L.; Pang, H.; Zhu, C.D.; Zhang, Y.Z. Investigating the Parasitoid community associated with the invasive mealybug Phenacoccus solenopsis in Southern China. Insects 2021, 12, 290. [CrossRef]

29. Cao, Y.; Ren, J.; Cui, Z.; Chen, W. The development of IPM in our country and pests cortrol. Syst. Sci. Compr. Stud. Agric. 2002, 18, 69-70.

30. Paparella, F.; Ferracini, C.; Portaluri, A.; Manzo, A.; Alma, A. Biological control of the chestnut gall wasp with T. sinensis: A mathematical model. Ecol. Model. 2016, 338, 17-36. [CrossRef]

31. Kos, K.; Kriston, E.; Melika, G. Invasive chestnut gall wasp Dryocosmus kuriphilus (Hymenoptera: Cynipidae), its native parasitoid community and association with oak gall wasps in Slovenia. Eur. J. Entomol. 2015, 112, 698-704. [CrossRef]

32. Nieves-Aldrey, J.L.; Gil-Tapetado, D.; Gavira, O.; Boyero, J.R.; Polidori, C.; Lombardero, M.J.; Blanco, D.; del Castillo, C.R.; Rodriguez-Rojo, P.; Vela, J.M.; et al. Torymus sinensis Kamijo, a biocontrol agent against the invasive chestnut gall wasp Dryocosmus kuriphilus Yasumatsu in Spain: Its natural dispersal from France and first data on establishment after experimental releases. For. Syst. 2019, 28, 3. [CrossRef]

33. Bonsignore, C.P.; Bernardo, U. Effects of environmental parameters on the chestnut gall wasp and its complex of indigenous parasitoids. Sci. Nat. 2018, 105, 20. [CrossRef]

34. Bhede, B.V.; Bhosle, B.B.; Shinde, S.T.; Sharma, O.P. Ecofriendly integrated pest management in pigeonpea. J. Entomol. Res. 2014, 38, 259-263.

35. Triapitsyn, V.A. Parasitic Hymenoptera of the family Encyrtidae of Palaearctics. Opredelitelipo Faune SSSR Izdavaemiye Zoologiya 1989, 158, 251-263.

36. Triapitsyn, S.V. A new species of the genus Aprostocetus westwood, 1833 (Hymenoptera, Eulophidae: Tetrastichinae) collected by E. S. Sugonjaev in galls on saxauls in Uzbekistan. Entomol. Obozr. 2015, 94, 455-458. [CrossRef]

37. Noyes, J.S.; Hayat, M. A review of the genera of Indo-Pacific Encyrtidae (Hymenoptera: Chalcidoidea). Bull. Br. Mus. Entomol. 1984, 48, 131-395.

38. Noyes, J.S.; Woolley, J.B.; Zolnerowic, G. Encyrtidae. In Annotated Keys to the Genera of Nearctic Chalcidoidea (Hymenoptera); Gibson, G.A.P., Huber, J.T., Woolley, J.B., Eds.; NRC Research Press: Ottawa, ON, Canada, 1997.

39. Muhetaier, N.; Chen, G.-H.; Peng, J.; Gao, B.; Zhang, X.D.; Xi, O.Y.; Aishan, J.; Hu, H.Y. DNA barcoding of Anagrus dmitrievi (Hymenoptera, Mymaridae). Chin. J. Appl. Entomol. 2021, 58, 335-346. [CrossRef]

40. Li, Y.; Zhou, X.; Feng, G.; Hu, H.; Niu, L.; Hebert, P.D.N.; Huang, D. COI and ITS2 sequences delimit species, reveal cryptic taxa and host specificity of fig-associated Sycophila (Hymenoptera, Eurytomidae). Mol. Ecol. Resour. 2010, 10, 31-40. [CrossRef] [PubMed]

41. Rugman-Jones, P.F.; Hoddle, M.S.; Stouthamer, R. Nuclear-Mitochondrial barcoding exposes the global pest western flower thrips (Thysanoptera: Thripidae) as two sympatric cryptic species in its native California. J. Econ. Entomol. 2010, 103, 877. [CrossRef] [PubMed]

42. Triapitsyn, S.V.; Rugman-Jones, P.F.; Tretiakov, P.S.; Daane, K.M.; Wilson, H. Reassessment of molecular and morphological variation within the Anagrus atomus species complex (Hymenoptera: Mymaridae): Egg parasitoids of leafhoppers (Hemiptera: Cicadellidae) in Europe and North America. J. Nat. Hist. 2020, 54, 1735-1758. [CrossRef]

43. Morse, J.G.; Rugman-Jones, P.F.; Woolley, J.B.; Heraty, J.M.; Triapitsyn, S.V.; Hofshi, R.; Stouthamer, R. Armored scales and their parasitoids on commercial avocados grown in California or imported from Mexico. J. Econ. Entomol. 2016, 109, $2032-2042$. [CrossRef] [PubMed]

44. Colazza, S.; Bin, F. Efficiency of Trissolcus basalis (Hymenoptera: Scelionidae) as an egg parasitoid of Nezara viridula (Heteroptera: Pentatomidae) in Central Italy. Environ. Entomol. 1995, 24, 1703-1707. [CrossRef]

45. Virla, E.G.; Van Nieuwenhove, G.A.; Palottini, F.; Triapitsyn, S.V.; Logarzo, G.A. Spatial and seasonal distribution of egg parasitoids of the sharpshooter Tapajosa rubromarginata (Hemiptera: Cicadellidae: Proconiini) on feral Johnson grass and commercial citrus host in Argentina. Biol. Control 2019, 132, 81-88. [CrossRef]

46. Burckhardt, D.; Ouvrard, D.; Queiroz, D.; Percy, D. Psyllid host-plants (Hemiptera: Psylloidea): Resolving a semantic problem. Fla. Entomol. 2014, 97, 242-246. [CrossRef]

47. Hodkinson, I.D. The biology and ecology of the gall-forming Psylloidea (Homoptera). In Biology of Gall Insects; Ananthakrishnan, T.N., Ed.; Oxford University Press: London, UK, 1984.

48. Yang, M.M.; Raman, A. Diversity, richness, and patterns of radiation among gall-inducing psyllids (Hemiptera: Psylloidea) in the orient and eastern Palearctic. Orient. Insects 2007, 41, 55-65. [CrossRef] 
49. Yang, M.M.; Liao, L.H.; Lou, M.F.; Chen, W.C.; Huang, S.S.; Tung, G.S.; Weng, Y.C.; Shen, C.C. Diversity, Biology, and Nutritional Adaptation of Psyllids and their Galls in Taiwan. In Galling Arthropods and Their Associates; Ozaki, K., Yukawa, J., Ohgushi, T., Price, P.W., Eds.; Springer: Tokyo, Japan, 2006.

50. Sardon-Gutierrez, S.; Gil-Tapetado, D.; Gomez, J.F.; Nieves-Aldrey, J.L. Ecological niche modelling of species of the rose gall wasp Diplolepis (Hymenoptera: Cynipidae) on the Iberian Peninsula. Eur. J. Entomol. 2021, 118, 31-45. [CrossRef]

51. Cho, G.; Malenovský, I.; Burckhardt, D.; Inoue, H.; Lee, S. DNA barcoding of pear psyllids (Hemiptera: Psylloidea: Psyllidae), a tale of continued misidentifications. Bull. Entomol. Res. 2020, 110, 521-534. [CrossRef]

52. Purcell, M.F.; Thornhill, A.H.; Wallenius, T.C.; Yeates, D.K.; Rowell, D.M. Plant host relationships of three lineages of the gall-inducing fly Fergusonina Malloch (Diptera: Fergusoninidae) on Eucalyptus L'Hérit. Arthropod-Plant Interact. 2017, 12, 133-145. [CrossRef]

53. Moraglio, S.T.; Tortorici, F.; Pansa, M.G.; Castelli, G.; Pontini, M.; Scovero, S.; Visentin, S.; Tavella, L. A 3-year survey on parasitism of Halyomorpha halys by egg parasitoids in northern Italy. J. Pest Sci. 2020, 93, 183-194. [CrossRef]

54. Stone, G.N.; Schonrogge, K. The adaptive significance of insect gall morphology. Trends Ecol. Evol. 2003, 18, 512-522. [CrossRef]

55. Hernández-López, M.; Hernández-Ortiz, V.; Castillo-Campos, G.; Fernandes, G.W. Size matters: Larger galls produced by Eutreta xanthochaeta (Diptera: Tephritidae) on Lippia myriocephala (Verbenaceae) predict lower rates of parasitic wasps. Arthropod-Plant Interact. 2021, 15, 615-625. [CrossRef]

56. Joseph, M.B.; Gentles, M.; Pearse, I.S. The parasitoid community of Andricus quercuscalifornicus and its association with gall size, phenology, and location. Biodivers. Conserv. 2011, 20, 203-216. [CrossRef]

57. Laszlo, Z.; Tothmeresz, B. The enemy hypothesis: Correlates of gall morphology with parasitoid attack rates in two closely related rose cynipid galls. Bull. Entomol. Res. 2013, 103, 326-335. [CrossRef] [PubMed]

58. Jiang, M.; Yao, Z.; Ren, Y.; Jiang, Z.; Gu, Y.; Wang, B.; Zhang, H. Study on the Structure Characteristics and Growth and Development of Leafy Galls in Haloxylon ammodendron. Acta Bot. Boreali-Occident. Sin. 2017, 37, 1749-1755.

59. Tang, X.; Zhang, Y.; Hu, H. Seven new record species of Psyllaephagus (Hymenoptera: Encyrtidae) from China. Entomotaxonomia 2016, 38, 63-78. [CrossRef]

60. Wang, J.L.; Lao, G.F.; Li, Y.W.; Yang, M.; Mo, Z.Q.; Dan, X.M. Effects of temperature and host species on the life cycle of Cryptocaryon irritans. Aquaculture 2018, 485, 49-52. [CrossRef]

61. Gopko, M.; Mironova, E.; Pasternak, A.; Mikheev, V.; Taskinen, J. Parasite transmission in aquatic ecosystems under temperature change: Effects of host activity and elimination of parasite larvae by filter-feeders. Oikos 2020, 129, 1531-1540. [CrossRef]

62. Bari, M.N.; Jahan, M.; Islam, K.S. Effects of Temperature on the life table parameters of Trichogramma zahiri (Hymenoptera: Trichogrammatidae), an egg parasitoid of Dicladispa armigera (Chrysomelidae: Coleoptera). Environ. Entomol. 2015, 44, 368-378. [CrossRef]

63. Dang Hoa, T.; Khac, P.; Ueno, T.; Takagi, M. Effects of temperature and host on the immature development of the parasitoid Neochrysocharis okazakii (Hymenoptera: Eulophidae). J.-Fac. Agric. Kyushu Univ. 2012, 57, 133-137.

64. Quacchia, A.; Moriya, S.; Bosio, G.; Scapin, I.; Alma, A. Rearing, release and settlement prospect in Italy of Torymus sinensis, the biological control agent of the chestnut gall wasp Dryocosmus kuriphilus. BioControl 2008, 53, 829-839. [CrossRef]

65. Sangtongpraow, B.; Charernsom, K. Biological traits of Quadrastichus mendeli (Hymenoptera, Eulophidae), parasitoid of the eucalyptus gall wasp Leptocybe invasa (Hymenoptera, Eulophidae) in Thailand. Parasite 2019, 26, 8. [CrossRef] [PubMed] 